\title{
Mogok Kerja Buruh Berdampak Pemutusan Hubungan Kerja
}

\author{
Sahur Ramsay \\ Fakultas Hukum, Universitas Muhammadiyah Sorong \\ Email : sahur_ramsay@yahoo.com
}

\begin{abstract}
Abstrak
Penelitian ini bertujuan untuk mengetahui, menganalisis dan menjelaskan mogok kerja yang merupakan hak normatif dari buruh, yang telah mendapat legitimasi dari peraturan perundangundangan. Mogok kerja sebagai sarana untuk menyamakan kedudukan dengan pengusaha akan tetapi berdampak pemutusan hubungan kerja.

Penelitian ini dilakukan dengan metode normatif empiris. Penelitian normatif dilakukan dengan penelitian kepustakaan untuk memperoleh data sekunder melalui studi dokumen. Penelitian empiris dilakukan dengan penelitian lapangan untuk memperoleh data primer melalui wawancara dengan subjek peneliti. Data yang diperoleh dianalisis secara kualitatif dan hasilnya disampaikan secara deskriptif. Berdasarkan penelitian dan Pembahasan, maka penulis menyimpulkan Mogok kerja merupakan hak dasar yang secara eksplisit disebutkan dalam undang-undang ketenagakerjaan, Sebagai hak dasar maka keberadaannya harus dihormati oleh setiap orang tidak terkecuali pengusaha. Mogok kerja bukan sesuatu yang "liar", mogok kerja harus dilakukan dengan etika yang baik. Mogok kerja yang baik, apabila dilakukan sesuai dengan prosedur peraturan perundang-undangan. Adapun prosedur untuk melakukan mogok kerja sebagaimana tercantum dalam Pasal 140 UUK dan Pasal 3 KEP.232/MEN/2003 tentang Akibat Hukum Mogok Kerja Yang Tidak Sah:

Prosedur yang ditetapkan dalam undang-undang ketenagakerjaan dan KEP.232/MEN/2003 tentang Akibat Hukum Mogok Kerja Yang tidak Sah, untuk melakukan mogok kerja yang sah, sangat memberatkan bagi pihak buruh. Pada saat peneliti melakukan penelitian di Dinas Nakertrans Kab Sleman, Dinas Nakertrans Kab Bantul dan Dinas Sosnakertrans Kota Jogja, peneliti tidak mendapatkan kasus mogok kerja yang dilakukan oleh buruh sesuai dengan prosedur perundangundangan. Menurut Ari Hernawan kemungkinan kecil bagi pekerja atau serikat pekerja yang mogok kerja untuk dapat memenuhi prosedur tersebut. Prosedur mogok kerja yang sudah diakomodasikan dalam undang-undang ketenagakerjaan tersebut sangat berat untuk dilaksanakan pekerja. Ketentuan mengenai prosedur mogok kerja dalam Undang-Undang Nomor 13 tahun 2003 sangat membatasi ruang gerak pekerja untuk mogok sehingga hak mogok menjadi sulit dilaksanakan secara sah, padahal mogok adalah hak dasar pekerja dan organisasi pekerja yang seharusnya dipermudah untuk pelaksanaannya.
\end{abstract}

KATA KUNCI : Mogok Kerja, Pemutusan Hubungan Kerja Dan Hukum Positif

\section{PENDAHULUAN}

Bangsa Indonesia menyadari bahwa pekerjaan merupakan kebutuhan asasi warga negara sebagaimana tercantum dalam Konstitusi Pasal 27 ayat (2) dan Pasal 28D ayat (2) Undang-Undang Dasar Negara Republik Indonesia 1945 yang menyatakan : Tiap-tiap warga berhak atas pekerjaan dan penghidupan yang layak bagi kemanusiaan. Dan Setiap pekerja berhak untuk bekerja dan mendapatkan imbalan dan perlakuan yang adil dan layak dalam hubungan kerja. Pasal 41 ayat (1) Undang-Undang Nomor 13 Tahun 2003 tentang Ketenagakerjaan, yang selanjutnya disebut UUK menyatakan pemerintah menetapkan kebijakan ketenagakerjaan dan perluasan kesempatan kerja. Hak memperoleh pekerjaan 
(right to work) bagi setiap orang atau warga negara berimplikasi pada kewajiban negara untuk memfasilitasi warga negara agar memperoleh pekerjaan yang layak bagi kemanusiaan.

Angka angkatan kerja yang tiap tahunnya meningkat mengharuskan pemerintah membuat suatu policy yang berorientasi pada penciptaan lapangan kerja dan pemberdayaan usaha mikro, kecil dan menengah. Keterlibatan perusahaan multinasional tidak kalah urgen untuk meningkatkan pertumbuhan ekonomi. Sehingga, penyerapan tenaga kerja ke pasar kerja dapat mengurangi pengangguran.

Ikut andilnya perusahaan multinasional di Indonesia bukan tanpa pertimbangan, yang sering menjadi pertimbangan yaitu kekayaan sumber daya alam dan melimpahnya tenaga kerja murah serta kondisi ketenagakerjaan yang kondusif. Kondusifnya iklim ketenagakerjaan lebih ditekankan pada regulasi yang cenderung berpihak kepada kepentingan pengusaha. Orientasi pengusaha untuk mendapatkan keuntungan yang sebesar-besarnya dengan menekan biaya produksi. Stategi yang dilakukan oleh pengusaha untuk efesiensi biaya produksi (cost of production) dengan menghemat pengeluaran untuk membiayai sumber daya manusia yang bekerja di perusahaan tersebut.

Hubungan industrial antara pekerja/buruh dan pengusaha tidak selamanya terjalin dengan harmonis dan dinamis, tidak tertutup kemungkinan setiap saat hubungan itu akan diwarnai perselisihan. Pemeo menyatakan, perselisihan hubungan industrial senantiasa akan terjadi, sepanjangan masih ada pekerja/buruh dan pengusaha. Hal itu dipicu dari adanya perbedaan kepentingan antara pekerja/buruh dan pengusaha. Pekerja dalam bargaining position yang lemah diperlakukan dengan sewenang-wenang, upah pekerja bernilai asimetris dengan produktifitasnya, tenaga diperas tanpa penghargaan yang pantas.

Kondisi seperti itu banyak cara yang digunakan oleh pekerja untuk menunjukan ketidakpuasannya baik secara terorganisasi maupun tidak. Pada umumnya pekerja menunjukan bentuk-bentuk konflik untuk mengubah kondisi yang dianggap tidak memuaskan mencakup tindakan-tindakan seperti pemogokan, bekerja lambat, larangan lembur dan bahkan hanya duduk-duduk di tempat kerja.

Mogok kerja (strike) dilakukan oleh pekerja/buruh sebagai alternatif terakhir (last resource) untuk menyelesaikan perselisihan hubungan industrial, jika cara-cara damai yang ditempuh tidak menemukan titik temu. Mogok kerja dapat disebabkan oleh hal-hal sebagai berikut: (1) Belum terlaksananya hubungan kemitraan di tempat kerja. Sikap pengusaha memandang pekerja hanya sebagai faktor produksi serta hanya berorientasi mencari keuntungan semata. Penyebab lainnya adalah kurangnya rasa memiliki (sense of belonging) dari pekerja terhadap perusahaan dimana pekerja bekerja. Pekerja cenderung untuk 
mendapatkan upah yang besar tanpa harus bekerja keras.; (2) Kegagalan perundingan yang dilakukan oleh para pihak dalam menyelesaikan perselisihan perburuhan yang terjadi sebagai akibat ketiadaan hubungan komunikasi yang baik dan efektif. Penyebabnya adalah belum adanya lembaga-lembaga yang berfungsi sebagai forum komunikasi dimana partisipasi kaum pekerja dapat dilaksanakan.; (3) Lamanya proses penyelesaian perselisihan perburuhan. Mogok kerja sebagai "senjata" untuk menyeimbangankan posisi pekerja/buruh dengan pihak pengusaha. Mogok kerja sebagai alat untuk menuntut hak-hak normatif yang diamputasi oleh pengusaha berakhir dengan pemutusan hubungan kerja. Berdasarkan uraian di atas, maka penulis kemudian tertarik untuk melakukan penelitian lebih lanjut dengan Judul "Analisis Mogok Kerja Buruh Berdampak Pemutusan Hubungan Kerja Berdasarkan Undang-Undang Nomor 13 Tahun 2003 tentang Ketenagakerjaan (Studi Kasus Mogok Kerja Awak Mobil Tangki pada PT PTC, D.I.Yogyakarta)".; (1) Bagaimana mekanisme mogok kerja yang sah berdasarkan hukum positif yang berlaku?

\section{PEMBAHASAN}

\section{Mekanisme Mogok Kerja Sah Berdasarkan Hukum Positif Yang Berlaku}

Hubungan kerja merupakan hubungan yang terjalin antara penerima kerja dan pemberi kerja berdasarkan perjanjian kerja/kesepakatan kerja, baik untuk waktu tertentu maupun untuk waktu tidak tertentu yang mengandung adanya unsur pekerjaan, upah dan hubungan di bawah perintah. Hubungan kerja menjadi hubungan hukum ketika adanya perjanjian kerja. Perjanjian kerja dibuat untuk perlindungan dan kepastian akan hak dan kewajiban masing-masing pihak. Hubungan kerja sebagai realisasi dari perjanjian kerja, hendaknya menunjukkan kedudukan masing-masing pihak yang pada dasarnya akan menggambarkan hak-hak dan kewajiban-kewajiban pengusaha terhadap pekerja secara timbal balik.

Pekerja awak mobil tangki yang selanjutnya disebut (AMT) yang terdiri dari supir dan kernet berjumlah 194 orang dengan PT Pertamina Training and Consulting yang selanjutnya disebut (PT PTC) di Terminal Bahan Bakar Minyak Rewulu Kabupaten Bantul, melakukan hubungan kerja. Hubungan kerja didasarkan pada perjanjian kerja waktu tertentu. Dalam perjanjian tersebut ditentukan perjanjian kerja berlaku mulai tanggal 1 September 2012 sampai dengan 31 Agustus 2014. Perjanjian PT PTC dengan AMT didasarkan pada perjanjian Nomor: /PTC/KK/VII/2012, tanggal 1 Agustus 2012.

PT PTC merupakan perusahaan penyedia jasa tenaga kerja bagi PT Pertamina Patra Niaga selanjutnya disebut PT PPN, sedangkan PT PPN adalah perusahaan yang mendapatkan 
penugasan dari PT Pertamina (Persero) untuk melaksanakan pengoperasian kendaraan, operasional mobil tangki terminal bahan bakar minyak yang wilayah kerjanya meliputi daerah Jawa dan Madura guna melayani konsumsi bahan bakar minyak. Perjanjian yang melandasi hubungan PT Pertamina (Persero) dengan PT PPN sama dengan perjanjian yang melandasi hubungan antara PT PPN dengan PT PTC yakni perjanjian Nomor: 799/PN000.201/KTR/2012 tanggal 22 Oktober 2012. Dalam melaksanakan pengoperasian mobil tangki PT PPN berkerja sama dengan PT PTC dan PT PTC merekrut pekerja (AMT) untuk mengoperasikan mobil-mobil tangki yang akan menyuplai BBM pada tiap-tiap SPBU di D.I Yogyakarta. Jadi, perjanjian antara PT PPN dengan PT PTC merupakan perjanjian penyedia jasa pekerja.

Hubungan kerja tidak selamanya berjalan harmonis dan dinamis, perselisihan dan perbedaan pandangan/pendapat akan mewarnai hubungan industrial. Perbedaan pendapat/pandangan para pihak (pengusaha dan pekerja) menyebabkan Pekerja AMT melaporkan PT PTC pada instansi yang membidangi ketenagakerjaan mengenai perbedaan pandangan (kelebihan jam kerja). Tepatnya tanggal 21 Maret 2013, Pihak AMT melaporkan ke Dinas Tenaga Kerja dan Transmigrasi Kabupaten Bantul dengan laporan bahwa para pekerja/buruh AMT dipekerjakan melebihi jam kerja. Waktu bekerjanya AMT jam 07.00 sampai selesai, selesainya tidak mempunyai batas waktu terkadang sampai jam 22.00. Jika, memasuki H- 10 sebelum Hari Raya Idul Fitri sampai H+ 10 setelah Idul Fitri pekerja diharuskan piket sampai jam 22.00. Atas kelebihan waktu kerja yang dialami oleh pekerja, pihak pengusaha tidak memberikan upah kerja lembur. Menanggapi laporan dari pekerja AMT, satu minggu kemudian tepatnya tanggal 28 Maret 2013, pegawai pengawas ketenagakerjaan Kabupaten Bantul melakukan pemeriksaan di PT PTC. Dari hasil pemeriksaan diperoleh informasi bahwa PT PTC mempekerjakan AMT melebihi jam kerja tetapi tidak memberikan upah kerja lembur terhadap kelebihan jam kerja, sehingga pegawai pengawas ketenagakerjaan mengeluarkan Nota Pemeriksaan I Nomor: 561/927 tanggal 15 April 2013.

Kisruh yang terjadi antara PT PTC dengan AMT mengenai upah lembur, menyebabkan PT PPN sebagai user mempunyai kewajiban untuk mengklarifikasi persoalan tersebut. Pada tanggal 26 April 2013, personalia PT PPN mendatangi Kantor Dinas Tenaga kerja dan Transmigrasi Kabupaten Bantul selanjutnya disebut Dinas Nakertrans Kab Bantul, untuk memberikan penjelasan mengenai upah lembur. Pernyataannya bahwa, AMT telah diberikan upah lembur dengan nama lain yaitu Tunjangan performansi, yang menurut PT PPN hasil yang diperoleh lebih besar dari upah kerja lembur. 
Datangnya PT PPN pada Kantor Dinas Nakertrans Kab Bantul dalam memberikan informasi tentang upah kerja lembur yang sama dengan tunjangan performansi, membuat pegawai pengawas ketenagakerjaan melakukan pemeriksaan kembali ke PT PPN dan PT PTC. Pada tanggal 2 Mei 2013, pegawai pengawas ketenagakerjaan melakukan pemeriksaan untuk mendapat bahan dan penjelasan mengenai tunjangan performansi. Setelah dipelajari dan ditelaah ternyata tunjangan performansi tidak berhubungan dengan upah kerja lembur. Tunjangan performansi merupakan tunjangan yang didasarkan pada kinerja, sedangkan upah lembur diberikan apabila pekerja bekerja melebihi jam kerja yang telah ditentukan undangundang.

Menurut Bahari,performansi dan upah kerja lembur adalah dua hal yang berbeda, upah lembur didasarkan pada kelebihan jam kerja sedangkan performansi didasarkan pada pencapaian target atau didasarkan pada kinerja.

Nota Pemeriksaan I yang dikeluarkan oleh pegawai pengawas ketenagakerjaan tidak mendapat respon dari pihak PTC, sehingga pegawai pengawas ketenagakerjaan mengeluarkan Nota Pemeriksaan II pada tanggal 13 Mei 2013. Atas terbitnya Nota Pemeriksaan II, PT PTC memberikan tanggapan melalui surat Nomor: 343/PTCRTCOS/V/2013 tanggal 21 Mei 2013, perihal tanggapan atas Nota Pemeriksaan I dan II. PT PTC melalui surat tersebut menyatakkan bahwa perusahaan (PT PTC) tidak dapat memberikan upah lembur dengan mendasarkan pada perjanjian kerja. Perjanjian kerja antara PT PTC dengan personil AMT tidak menyebutkan pemberian upah kerja lembur kepada AMT. Perjanjian yang telah disepakati bersama wajib ditaati, dilaksanakan dengan itikad baik yang berlaku sebagai undang-undang bagi kedua belah pihak yang membuat perjanjian tersebut sebagaimana dalam Pasal 1338 KUH Perdata.

Menurut Direktur utama PT PTC apabila terjadi keberatan dan terjadi ketidaksepahaman tentang sistem kerja maupun sistem pembayaran upah tunjangan performansi, mengenai perjanjian/kontrak kerja yang dibuat antara PT PTC dengan para AMT tersebut dari kewajiban timbal balik yang tidak terpenuhi atas prestasinya, maka menurut undang-undang salah satu pihak tidak boleh membatalkan menurut kehendaknya sendiri dan menuntut diluar kesepakatan yang telah dibuat sebelumnya. Ketentuan Pasal 55 UUK berbunyi perjanjian kerja tidak dapat ditarik kembali dan/atau diubah, kecuali atas persetujuan para pihak.

Tanggapan PT PTC yang tidak memberikan upah kerja lembur didasarkan pada perjanjian kerja menyebabkan pegawai pengawas ketenagakerjaan Kab. Bantul ingin mengetahui perjanjian kerja tersebut. Keingintahuan pegawai pengawas ketenagakerjaan 
pupus disebabkan PT PTC Kab. Bantul tidak berwenang mengeluarkan data yang diperlukan sebelum mendapatkan izin dari kantor pusat yang berkedudukan di Jakarta Selatan.

PT PTC yang tidak mendaftakan perjanjian kerja pada instansi yang bertanggung jawab di bidang ketenagakerjaan (Dinas Nakertrans Kab Bantul) melanggar peraturan perundang-undangan, menurut Raharjo, perjanjian wajib didaftarkan pada instansi yang bertanggung jawab untuk mengetahui perjanjian kerja tersebut seimbang (balance) atau tidak seimbang. Karena dalam perjanjian tersebut memuat hak dan kewajiban para pihak yang membuat perjanjian. Perusahaan yang tidak mendaftarkan perjanjian kerja maka, ada indikasi etika tidak baik dari perusahaan.

Terbatasnya akses untuk memperoleh perjanjian kerja antara PT PTC dengan AMT dan semakin meluasnya permasalahan terminal bahan bakar. Maka, tindak lanjut pemeriksaan kasus tersebut Dinas Nakertrans Kab Bantul mohon bantuan dan petunjuk Kepala Dinas Tenaga Kerja dan Transmigrasi D.I.Yogyakarta untuk menyelesaikannya.

Dinas Naketrans D.I.Yogyakarta menanggapi permintaan dari Dinas Nakertrans Kab Bantul, dengan melakukan penelitian di lapangan. Dari hasil penelitian di lapangan pihak Dinas Nakertras D.I.Yogyakarta menyimpulkan bahwa AMT tidak mempunyai hak mendapat upah kerja lembur, karena pengendalian jam kerja sulit dilakukan dan belum ada aturan khusus mengenai supir angkutan jarak jauh. Untuk menyelesaikan perselisihan tersebut pihak Dinas Nakertrans D.I.Yogyakarta memanggil AMT dan PT PTC. Dalam proses klarifikasi dan mediasi tidak memperoleh penyelesaian sehingga kasus dilimpahkan pada Kementerian Tenaga Kerja dan Transmigrasi RI. Dinas Nakertrans D.I.Yogyakarta mengeluarkan surat Nomor: 565/5202 tanggal 26 Juli 2013, ke Direktoral Jendral Pembinaan dan Pengawasan Tenaga Kerja Kementerian Tenaga Kerja selanjutnya disebut Dirjen Binwasnaker Kemnakertrans RI dan Transmigrasi Republik Indonesia yang subtansinya memohon bantuan tindak lanjut ke Kementerian Tenaga kerja dan Transmigrasi RI mengingat kasus tersebut terjadi di beberapa Provinsi.

Kementrian Tenaga Kerja dan Transmigrasi RI mengeluarkan surat Nomor: B. 335/PPK/X/2013 tanggal 11 Oktober 2013, yang ditujukan kepada beberapa Dinas Nakertrans Provinsi, pokok isinya adalah sektor usaha atau pekerjaan tertentu yang mempunyai karakteristik tertentu belum diatur secara khusus sebagaimana dimaksud pada Pasal 77 ayat (2) UUK, maka berlaku aturan waktu kerja dan waktu istrahat secara umum (Kepmenakertrans No. KEP.102/MEN/IV/2004 tentang Waktu Kerja dan Upah Kerja Lembur). Dalam surat tersebut pula pihak Kementerian Tenaga Kerja dan Transmigrasi meminta bantuan Provinsi untuk menyelesaikan kasus kerja lembur. 
Menanggapi permintaan dari Kemetrian Tenaga Kerja dan Transmigrasi, Dinas Nakertrans D.I.Yogyakarta mengirim surat ke Dinas Nakertrans Kab. Bantul melalui surat: 566/7072 tanggal 21 Oktober 2013, yang isinya meminta kepada pegawai pengawas ketenagakerjaan Kab. Bantul untuk menyelesaikan perhitungan upah kerja lembur bagi AMT. Pada tanggal 29 Oktober 2013, Dinas Nakertrans Kab Bantul mengirimkan surat ke PT PTC melalui surat Nomor: 568/2606 yang isinya meminta data jam kerja AMT dan daftar upah pekerja dari bulan September 2012 s/d Juli 2013.

Pihak PT PTC menanggapi surat tersebut dengan memberikan balasan dengan Nomor surat: 535/PTC-DK11010/2013-S2 yang dikeluarkan pada tanggal 8 November 2013, yang subtansinya PT PTC tidak menerima surat tembusan dari Kementerian Tenaga Kerja dan Transmigrasi RI Nomor: B.335/PPK/X/2013 maka pihak perusahaan akan mempelajari lagi dan dalam proses pencarian data yang diminta.

Tanggal 8 Januari 2014, Dirjen Binwasnaker Kemnakertrans RI mengeluarkan surat Nomor: B.04/PPK/I/2014 tentang Penentuan Komponen Perhitungan Upah Lembur ditujukan kepada Dinas Nakertrans Provinsi. Pokok isinya adalah tunjangan performansi termaksud kategori bonus dan bukan merupakan upah kerja lembur. Serta memerintahkan kepada Dinas Nakertrans Provinsi untuk menghitung dan menetapkan besarnya upah lembur, apabila pihak perusahaan tidak melaksanakan kewajibannya maka akan dilimpahkan ke pegawai pengawas negeri sipil ketenagakerjaan untuk melakukan upaya penegakan hukum (pro justicia).

Dinas Nakertrans D.I.Yogyakarta menanggapi surat dari Kementerian Tenaga Kerja dan Transmigrasi RI dengan mengeluarkan surat Nomor: 566/439 Januari 2014, yang subtansinya mengundang Dinas Nakertrans Kab. Bantul untuk hadir tanggal 27 Januari 2014, di Ruang Seksi Pengawasan Ketenagakerjaan Dinas Nakertrans D.I.Yogyakarta, mengikuti acara rapat koordinasi penentuan komponen perhitungan upah lembur AMT. Hasil dari rapat tersebut, dianjurkan kepada Dinas Nakertrans Kab Bantul, untuk menghitung dan menetapkan upah kerja lembur AMT dengan meminta data kembali ke PT PTC untuk keperluan perhitungan upah kerja lembur AMT.

Menindak lanjuti hasil rapat tersebut Dinas Nakertrans Kab Bantul mengeluarkan surat: 568/181 tanggal 5 Februari 2014, yang isinya meminta kembali data jam kerja AMT dan apabila tidak dilaksanakan akan dilakukan upaya penegakan hukum oleh pegawai pengawas negeri sipil. Menanggapi surat tersebut pihak pengusaha mengirim surat balasan dengan Nomor: 472/PTC-DKI 1010/2014-S2 tanggal 20 Februari 2014, perihal penjelasan penentuan komponen perhitungan upah lembur. Perusahaan tidak dapat mengirim data yang diminta dikarenakan beberapa alasan diantaranya: sedang berjalan persidangan di Pengadilan 
Hubungan Industrial Jakarta Pusat mengenai tuntutan lembur AMT dan telah ada kesepakatan upah terbaru pada akhir Juli 2013 yang telah didaftarkan di Pengadilan Hubungan Industrial Yogyakarta.

Habisnya tenggang waktu yang diberikan oleh pihak Dinas Nakertrans Kab Bantul dan tidak ada tanggapan dari pihak pengusaha maka, pihak Dinas Nakertrans Kab Bantul, bersurat ke Dinas Nakertrans D.I.Yogyakarta dengan Surat: 568/420 tanggal 27 Februari 2014, yang subtansinya memohon agar pegawai pengawas negeri sipil ketenagakerjaan Dinas Nakertrans D.I.Yogyakarta melakukan upaya penegakan hukum (pro justicia). Pihak Dinas Nakertrans D.I.Yogyakarta mengundang Dinas Nakertrans Kab Bantul untuk hadir di ruangan pengawasan ketenagakerjaan Dinas Nakertrans D.I.Yogyakarta melalui surat Nomor: 566/1441 tanggal 6 Maret 2014. Hasil rapat tersebut Dinas Nakertrans Kab Bantul diminta untuk membuat penetapan upah lembur berdasarkan data yang ada. Apabila perusahaan tidak memberikan data yang diperlukan, maka dari pengakuan AMT dapat digunakan dasar perhitungan upah lembur. Apabila penetapan telah dikirimkan ke perusahaan tetapi tidak dilaksanakan maka tindak lanjutnya adalah dibuat laporan kejadian untuk selanjutnya masuk ke penyidikan (pro justicia).

Menindak lanjuti rapat koordinasi tersebut Dinas Nakertrans D.I.Yogyakarta mengeluarkan surat Nomor: 566/1680 tanggal 14 Maret 2014, kepada Dinas Nakertrans Kab. Bantul yang isinya Dinas Nakertrans Kab. Bantul diminta untuk membuat penetapan upah lembur AMT berdasarkan data yang diserahkan oleh AMT disebabkan dari pihak perusahaan tidak memberikan data. Dinas Nakertrans Kab Bantul mengeluarkan Nota Pemeriksaan III Nomor: 560/680 tanggal 28 Maret 2014 dan penetapan upah lembur awak mobil tangki Nomor: 568/660 pada tanggal 25 Maret 2014. Dengan keluarnya Nota Pemeriksaan III dan penetapan tidak ditanggapi oleh perusahaan sampai tenggang waktu habis.

Tetap bergeming PT PTC dari anjuran Dinas Nakertrans Kab Bantul untuk membayarkan upah kerja lembur. AMT yang upah kerja lemburnya tidak dibayarkan menempuh "senjata terakhir" untuk menuntut haknya. Mogok kerja sebagai "senjata terakhir" buruh tidak dapat dielakkan. Raharjo menyatakan mogok kerja merupakan solusi terakhir agar hak buruh/pekerja diperoleh, tetapi dalam melakukan mogok kerja harus mempunyai etika yang baik. Pekerja yang beretika baik, sebelum melakukan aksi mogok kerja minimal (7) tujuh hari kerja melakukan pemberitahuan pada pengusaha dan instansi yang bertanggung jawab di bidang ketenagakerjaan.

Serikat Pekerja Awak Mobil Tangki Perisai Bangsa Indonesia, selanjutnya disebut SPAMT-PBI. SPAMT-PBI tercatat dikantor Dinas Nakertrans dengan Nomor: 646/SPAMT- 
PBI/II/2014, tertanggal 12 Januari 2014. SPAMT-PBI pada tanggal 13 Mei 2014, melayangkan surat pemberitahuan mogok kerja, dengan Nomor: 013/SPAMT-PBI/V/PEMBMGK/VII/2014. Surat tersebut ditujukan kepada Direktur PT. Pertamina Training and Consulting dan Direktur PT Pertamina Patra Niaga Di TBBM Rewulu D.I.Yogyakarta, serta instansi yang bertanggung jawab di bidang ketenagakerjaan (Kepala Dinas Tenaga Kerja dan Transmigrasi D.I.Yogyakarta dan Kepala Dinas Tenaga Kerja dan Transmigrasi Kabupaten Bantul Yogyakarta). Subtansi surat berkenaan dengan aksi mogok kerja AMT yang akan dilakukan pada tanggal 26 Mei 2014.

Mogok kerja merupakan hak dasar yang secara eksplisit disebutkan dalam undangundang ketenagakerjaan, Sebagai hak dasar maka keberadaannya harus dihormati oleh setiap orang tidak terkecuali pengusaha. Mogok kerja bukan sesuatu yang "liar", mogok kerja harus dilakukan dengan etika yang baik. Mogok kerja yang baik, apabila dilakukan sesuai dengan prosedur peraturan perundang-undangan. Adapun prosedur untuk melakukan mogok kerja sebagaimana tercantum dalam Pasal 140 UUK dan Pasal 3 KEP.232/MEN/2003 tentang Akibat Hukum Mogok Kerja Yang Tidak Sah:

Ketentuan Pasal 140 UUK yang berbunyi: (1) Sekurang-kurangnya dalam waktu (7) tujuh hari kerja sebelum mogok kerja dilaksanakan pekerja/buruh dan serikat pekerja/serikat buruh wajib memberitahukan secara tertulis kepada pengusaha dan instansi yang bertanggung jawab di bidang ketenagakerjaan setempat; (2) Pemberitahuan sebagaimana dimaksud pada ayat (1) sekurang-kurangnya memuat: (a) Waktu (hari, tanggal, dan jam) dimulai dan diakhiri mogok kerja; (b) Tempat mogok kerja; (c) Alasan dan sebab-sebab mengapa harus melakukan mogok kerja, dan; (d) tanda tangan ketua dan sekretaris dan/atau masing-masing ketua dan sekretaris serikat pekerja/serikat buruh sebagai penanggungjawab mogok kerja.

Ketentuan Pasal 3 KEP.232/MEN/2003 tentang Akibat Hukum Mogok Kerja Yang Tidak Sah berbunyi, Mogok kerja tidak sah apabila dilakukan; (a) Bukan akibat gagalnya perundingan; dan atau; (b) Tanpa pemberitahuan kepada pengusaha dan instansi yang bertanggung jawab di bidang ketenagakerjaan; dan atau; (c) Dengan pemberitahuan kurang dari 7 (tujuh) hari sebelum pelaksanaan mogok kerja; dan atau; (d) Isi pemberitahuan tidak sesuai dengan ketentuan Pasal 140 ayat (2) huruf a, b, c, dan d Undang-Undang Nomor 13 tahun 2003 tentang Ketenagakerjaan

Prosedur yang ditetapkan dalam undang-undang ketenagakerjaan dan KEP.232/MEN/2003 tentang Akibat Hukum Mogok Kerja Yang tidak Sah, untuk melakukan mogok kerja yang sah, sangat memberatkan bagi pihak buruh. Pada saat peneliti melakukan penelitian di Dinas Nakertrans Kab Sleman, Dinas Nakertrans Kab Bantul dan Dinas 
Sosnakertrans Kota Jogja, peneliti tidak mendapatkan kasus mogok kerja yang dilakukan oleh buruh sesuai dengan prosedur perundang-undangan. Menurut Ari Hernawan kemungkinan kecil bagi pekerja atau serikat pekerja yang mogok kerja untuk dapat memenuhi prosedur tersebut. Prosedur mogok kerja yang sudah diakomodasikan dalam undang-undang ketenagakerjaan tersebut sangat berat untuk dilaksanakan pekerja. Ketentuan mengenai prosedur mogok kerja dalam Undang-Undang Nomor 13 tahun 2003 sangat membatasi ruang gerak pekerja untuk mogok sehingga hak mogok menjadi sulit dilaksanakan secara sah, padahal mogok adalah hak dasar pekerja dan organisasi pekerja yang seharusnya dipermudah untuk pelaksanaannya.

Mogok kerja yang dilakukan oleh AMT dianggap mogok kerja yang tidak sah dari pihak Dinas Nakertrans Kab Bantul. Pihak Dinas Nakertrans Bantul menyatakan mogok kerja AMT tidak memenuhi ketentuan Pasal 140 ayat (2) UUK dan Pasal 3 huruf (d) Kepmenakertrans RI Nomor: KEP.232/MEN/2003. Dalam surat pemberitahuan mogok tersebut ada beberapa hal yang belum terpenuhi yaitu; (a) Waktu hanya menyebut hari senin dan tanggal 26 Mei 2014 tanpa menyebutkan jam dimulai dan diakhiri mogok kerja. Pasal 142 ayat (1) UUK secara eksplisit menyebutkan mogok kerja yang dilakukan tidak memenuhi ketentuan sebagaimana dimaksud dalam Pasal 139 dan 140 UUK adalah tidak sah. Menurut Ari Hernawan Dalam surat pemberitahuan mogok kerja, harus mencantumkan kapan mogok akan diawali dan diakhiri (harus tercantum hari, tanggal dan jam pemogokan) sulit dipenuhi pekerja atau serikat pekerja yang mogok. Hal tersebut dikarenakan pekerja tidak dapat memastikan kapan mogok kerja berakhir, bergantung pada hasil perundingan dengan pengusaha. Bahkan dalam praktik ada beberapa pengusaha yang menolak berunding atau hanya mengirim wakil perusahaan untuk berunding yang biasanya tidak dapat membuat keputusan tanpa bertanya dahulu kepada pengusaha yang diwakilinya sehingga waktu perundingan menjadi berlarut-larut.; (b) Tempat mogok kerja disebutkan tidak secara jelas atau tidak spesifik menyebutkan lokasi, tetapi hanya dicantumkan "diseluruh wilayah Jawa Timur, Jawa Tengah dan D.I. Yogyakarta. Luasnya lokasi mogok kerja yang dicantumkan dalam surat pemberitahuan mogok disebabkan mogok yang dilakukan berlaku secara serentak dibeberapa wilayah di daerah Jawa. Dicantumkannya satu Provinsi misalnya D.I.Yogyakarta untuk memperluas wilayah mogok kerjanya, sehingga apabila mogok kerja dilakukan di Kepatihan atau DPRD, maka hal tersebut, sudah mencukupi. Karena jika membatasi mogok kerja hanya pada lokasi tertentu misalnya Perusahaan, akan sulit bagi pekerja/buruh untuk di dengar dan dipenuhi tuntutannya. Menurut Ari Hernawan memang sulit membatasi ruang gerak mogok hanya dalam lingkungan perusahaan. Ketika tuntutan pekerja yang mogok tidak 
dipenuhi pengusaha, biasanya pekerja akan menyalurkan aspirasi atau tuntutannya ke institusi atau lembaga yang dipandang akan mau mendengarkan tuntutan mereka.

Pandangan penulis, para AMT dalam melakukan aksi mogok kerja telah menunjukkan etika yang baik. Dari proses perundingan yang berlarut-larut, serta melibatkan instansi yang bertanggung jawab di bidang ketenagakerjaan (Dinas Nakertrans Kab Bantul, Dinas Nakertrans D.I.Yogyakarta sampai pada tingkat Kementerian Tenaga Kerja dan Transmigrasi Republik Indonesia) perundingan tidak menemukan titik terang. Sebelum melakukan aksi mogok SPAMT-PBI melayangkan surat pemberitahuan mogok kerja yang akan dilakukan pada tanggal 26 Mei 2014, sedangkan surat tersebut dikeluarkan pada tanggal 13 Mei 2014, ada jeda waktu 13 hari dari waktu melakukan mogok kerja. sehingga pihak Dinas Nakertrans dapat melakukan upaya damai dan pihak pengusaha dapat meminimalisir kerugian yang akan dialami. Motivasi para AMT melakukan mogok kerja untuk menuntut hak normatif (upah kerja lembur) yang diabaikan pengusaha. Tetapi etika baik tersebut dianulir oleh pihak Dinas Nakertrans dan dinilai sebagai mogok kerja yang tidak sah.

Menurut Ari Hernawan yang dikutip oleh Nailul Amany, mengkritisi mogok kerja sah yang pada kenyataanya sulit terpenuhi sebagai berikut: Pemogokan tidak lagi dilihat secara subtansial, apa yang menjadi sebab dan alasan mogok tetapi apakah mogok itu sudah memenuhi tata cara formal. Bisa dikatakan bahwa undang-undang ketenagakerjaan memang memandang mogok dalam kerangka formal belaka. Legalitas hukum suatu pemogokan diutamakan daripada subtansi. Karena mengedepankan formalitas apa yang menjadi subtansi mogokpun potensial menjadi terlupakan. Kondisi tersebut dapat menjadikan negara tidak mau peduli pada apa yang menjadi substansi pemogokan dan lebih mengurus soal tata cara dan prosedur mogok apakah sudah sesuai atau tidak sesuai dengan tata cara tersebut. Di luar prosedur tersebut mogok dianggap liar dan tidak sah dan karennya tidak mendapat perlindungan negara sebagaimana mogok sah.

Penulis menyimpulkan, eksekutif (Dinas Nakertrans Kab Bantul) dalam menyatakan mogok kerja yang dilakukan oleh AMT sah atau tidaknya, lebih terpaku pada pemenuhan tata cara formal yang tertuang dalam peraturan perundang-undangan, tanpa mempertimbangkan subtansial pemogokan yang dilakukan AMT.

\section{SIMPULAN}

Mogok kerja merupakan hak dasar yang secara eksplisit disebutkan dalam undangundang ketenagakerjaan, Sebagai hak dasar maka keberadaannya harus dihormati oleh setiap orang tidak terkecuali pengusaha. Mogok kerja bukan sesuatu yang "liar", mogok kerja harus 
dilakukan dengan etika yang baik. Mogok kerja yang baik, apabila dilakukan sesuai dengan prosedur peraturan perundang-undangan. Adapun prosedur untuk melakukan mogok kerja sebagaimana tercantum dalam Pasal 140 UUK dan Pasal 3 KEP.232/MEN/2003 tentang Akibat Hukum Mogok Kerja Yang Tidak Sah:

Prosedur yang ditetapkan dalam undang-undang ketenagakerjaan dan KEP.232/MEN/2003 tentang Akibat Hukum Mogok Kerja Yang tidak Sah, untuk melakukan mogok kerja yang sah, sangat memberatkan bagi pihak buruh. Pada saat peneliti melakukan penelitian di Dinas Nakertrans Kab Sleman, Dinas Nakertrans Kab Bantul dan Dinas Sosnakertrans Kota Jogja, peneliti tidak mendapatkan kasus mogok kerja yang dilakukan oleh buruh sesuai dengan prosedur perundang-undangan. Menurut Ari Hernawan kemungkinan kecil bagi pekerja atau serikat pekerja yang mogok kerja untuk dapat memenuhi prosedur tersebut. Prosedur mogok kerja yang sudah diakomodasikan dalam undang-undang ketenagakerjaan tersebut sangat berat untuk dilaksanakan pekerja. Ketentuan mengenai prosedur mogok kerja dalam Undang-Undang Nomor 13 tahun 2003 sangat membatasi ruang gerak pekerja untuk mogok sehingga hak mogok menjadi sulit dilaksanakan secara sah, padahal mogok adalah hak dasar pekerja dan organisasi pekerja yang seharusnya dipermudah untuk pelaksanaannya.

\section{DAFTAR PUSTAKA}

Agusmidah, dkk, Bab-Bab Tentang Hukum Perburuhan Indonesia, Pustaka Larasan, Jakarta, Budi Santoso, "Justifikasi Efisiensi Sebagai Alasan Pemutusan Hubungan Kerja", mimbar hukum,Fakultas Hukum Universitas Gadjah Mada, Vol. 25, Nomor 3 Oktober 2013.

Djumadi, 1992, Hukum Perburuhan Perjanjian Kerja, PT RajaGrafindo Persada, Jakarta

Fajar, Mukti dan Yulianto Achmad, 2010, Dualisme Penelitian Hukum Normatif dan Empiris, Pustaka Pelajar, Yogyakarta

Haryani, Sri, 2002, Hubungan Industrial Di Indonesia, UPP AMP YKPN, Yogyakarta

Hernawan, Ari, 2013, Ketidakadilan Dalam Norma dan Praktik Mogok Kerja Di Indonesia, Udayana University Press, Bali

Koeshartono. D dan M.F. Shellyana Junaedi, 2005, Hubungan Industrial Kajian Konsep dan Permasalahan, Universitas Atma Jaya, Yogyakarta

Tanya, Bernald L, Theodorus Yosep Parera, Samuel F Lena, 2015, Pancasila Bingkai Hukum Indonesia, Genta Publishing, Yogyakarta

Undang-Undang Nomor 13 Tahun 2003 tentang Ketenagakerjaan (Lembaran Negara Republik Indonesia Tahun 2003 Nomor 39, Tambahan Lembaran Negara Republik Indonesia Nomor 4279) 